\title{
MOLECULAR GENETIC IDENTIFICATION AND OLIVE LEAVES OIL COMPOSITION OF SOME EGYPTIAN OLIVE CULTIVARS
}

\author{
EZZ, THANAA M. ${ }^{1}$; A. I. ABIDO ${ }^{1}$; M. A. ALY ${ }^{1}$; \\ WAFAA T. SAEED ${ }^{2}$ and M. G. EL BARBARY ${ }^{2}$
}

1. Plant Production Department - Faculty of Agriculture (Saba Basha) - Alexandria University.

2. Olive and semi arid zone fruits Department, Horticulture Research Institute (HRI), $(A R C)$, Giza, Egypt.

(Manuscript received 22 December 2015)

\begin{abstract}

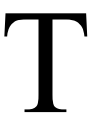
he present work was conducted to study the differences in leaves oil content as well as its fatty acids composition. Also, study the molecular genetic identification of three Egyptian olive Cultivars (Olea europaea L.) coined as Maraki, Aggezi Shami and Toffahi cultivated in the farm of Horticulture Research Institute. The oil content percentages in the dry leaves were (7.650, 6.046 and 4.754) for Maraki, Aggezi Shami and Toffahi, respectively. The main component of fatty acids were Linolenic acid methyl ester, Oleic acid, and palmitic acid. For molecular studies RAPD and ISSR-PCR were performed and efficient in detecting polymorphism and genetic variations within and between olive cultivars. In RAPD analysis, 4 selected primers displayed a total of 51 amplified fragments, in which 31 (60\%) were polymorphic fragments. Twenty eight out of 51 RAPD-PCR fragments were found to be useful as cultivar specific markers. Regarding the ISSR analysis, total of 46 out of 84 ISSR fragments were polymorphic. Twenty nine DNA amplified fragments were considered as cultivar-unique markers. Genetic similarities among the olive cultivars were estimated according to the fragments. In conclusion, both RAPD and ISSR polymorphisms could be used as efficient tools for the detection of similarities and phylogenetic relationships of the studied genotypes, which could be useful in the future breeding programs.
\end{abstract}

Key words: Olea europaea, olive oil composition; GC/MS, DNA fingerprinting, genetic relationship, molecular markers.

\section{INTRODUCTION}

The olive is native to the Mediterranean region, tropical and central Asia and to various parts of Africa. The genus Olea includes at least 30-35 species belonging to the family Oleaceae and subfamily Oleoideae $(x=23)$. The cultivated olive (Olea europaea L.) is an evergreen tree derived from tropical and subtropical species (Therios, 2009). Olea europaea L. is the only species from this genus adapted to the Mediterranean (Sanz-Cortes et al., 2001).

Olive cultivation is associated with several countries of the Mediterranean Sea basin and plays an important role in the diets, economies and cultures of the region 
(Zamora et al., 2001). Over the last three decades the Egyptian olive agro sub-sector has seen unprecedented development, the total acreage reached 240,004 feddans in 2013 according to statistical of the Ministry of Agriculture.

Chemically a fatty acid is a carboxylic acid, often with a carboxyl group at one end with a long unbranched aliphatic tail (chain), which is either saturated or unsaturated. The main fatty acids presenting as glycerides in olive oil are oleic (c18:1) "omega9", linoleic (c18:2) "omega6", linolenic acid (c18:3) "omega3", palmitic (c16:0) and stearic (c18:0). palmitoleic (c16:1), myristic (c14:0), arachidic (c20:0), behenic (c22:0), lignoceric (c24:0), heptadecanoic (c17:0), heptadecenoic (c17:1) and eicosenoic (c20:1) acids are the other minor fatty acids found in olive oil (Wiesman, 2009).

RAPD markers are based on polymerase chain reaction (PCR) amplification of random locations in the plant genome. Using this technique; a single oligonucleotide primer is used to prime the amplification of the genomic DNA Randomly amplified polymorphic DNA analysis was used to evaluate genetic variability and biodiversity present in some olive (Olea europaea) cultivars (Laz and Abd El-Razik, 2005). The RAPD technique is based on a PCR reaction and the use of short primers of an arbitrary nucleotide sequence, which results in amplification of an anonymous fragment (RAPD markers) of genomic DNA. The most important advantages of the RAPD technique are its technical simplicity and the fact that there is no need for advance knowledge of the DNA sequence. RAPD reproducibility among different laboratories and the requirement for strict experimental conditions are hard to achieve, which are the main disadvantages of this technique. This technically least demanding method (RAPD) became popular during the nineties and due to its ease of application, it is also used nowadays (Tomić et al., 2013).

Inter simple sequence repeat (ISSR) technique is a PCR based method, which involves amplification of DNA segment present at an amplifiable distance in between two identical microsatellite repeat regions oriented in opposite direction. ISSR markers are highly polymorphic and are useful in studies on genetic diversity (Reddy et al., 2002). Essadki et al. (2006) researched twelve olive cultivars representing the main domesticated material used in Morocco and nineteenolive cultivars used extensively in five countries of the western Mediterranean Basin. They were analyzed using intersimple sequences repeat (ISSR) markers which had never been used previously for extensive discrimination of cultivars.

The objective of the present investigation aimed to study oil content in leaves and the genetic identification of some Egyptian cultivars. 


\section{MATERIALS AND METHODS}

The study presented has been carried out at Central Laboratory and Biotechnology Laboratory in Horticulture Research Institute, Agricultural Research center, Giza.

Three Egyptian olive cultivars coined as Maraki, Aggezi Shami and Toffahi were used to study the differences in oil parentage in leaves as well as its chemical composition and molecular genetic identification between them. Olive leaves obtained from olive farm located at Horticulture Research Institute, Giza.

\section{Determination of leaves oil content ( $\mathrm{gm} / 100 \mathrm{gm}$ dried weight)}

The leaves dry weight oil percentage was determined by Soxhlet extraction apparatus as described in the A.O.A.C (2000).

The oils of a known weight of the leaves (5gm) were extracted with Petroleum ether for 18 hours in soxhlet apparatus. The solvent was evaporated and the residue was dried to a constant weight at 95C according to A.O.A.C. (2000). The percentage of oil content was then calculated on a dry weight basis.

\section{Determination of fatty acids:}

\section{Methylation of fatty acids}

An aliquot of fatty acids, about $10 \mathrm{mg}$, was dissolved in $2 \mathrm{ml}$ hexane, $0.4 \mathrm{ml}$ $2 \mathrm{~N} \mathrm{KOH}$ in anhydrous methanol was added (Cossignani et al., 2005), after 3min, 3ml water was added. The organic layer, separated by centrifugation, was dried over anhydrous sodium sulfate, and concentrated with a N2 stream to then it around 0.5 $\mathrm{ml}$ for GC analysis of fatty acids methyl esters.

\section{GC analysis of FAME}

Agilent 6890 series GC apparatus provided with a DB-23 column (60 m x 0.32 $\mathrm{mm} \times 0.25 \mu \mathrm{m})$ was used. Fatty acids methyl esters resulted from previous procedures steps were directly injected into the GC.

\section{Injection of sample:}

A sample (5 ul) was injected into the column using Hamilton microsyring.

The gas chromatographic conditions used for isothermal work were, column temperature $170 \mathrm{C}$, detector temperature $200 \mathrm{C}$, Range; $32 \times 100$, Attenuator $5 \mathrm{x}$ 122 , hydrogen flow rate $45 \mathrm{ml} / \mathrm{min}$, and chart speed $\mathrm{cm} / 2 \mathrm{~min}$.

\section{- Molecular analysis:}

\section{A- Random amplified polymorphic DNAs (RAPD) analysis}

A total of twenty random DNA oligonucleotide primers were independently used according to Williams et al. (1990) in the PCR reaction. Only four primers succeeded to generate reproducible polymorphic DNA products Table (1). The PCR 
amplification was performed in a $25 \mu$ reaction volume containing the following: 2.5 $\mu \mathrm{l}$ of dNTPs $(2.5 \mathrm{mM}), 1.5 \mu \mathrm{l}$ of $\mathrm{Mg} \mathrm{Cl} 2(25 \mathrm{mM}), 2.5 \mu \mathrm{l}$ of $10 x$ buffer, $2.0 \mu \mathrm{l}$ of primer $(2.5 \mu \mathrm{M}), 2.0 \mu \mathrm{l}$ of template DNA $(50 \mathrm{ng} / \mu \mathrm{l}), 0.3 \mu \mathrm{l}$ of Taq polymerase $(5 \mathrm{U} / \mu \mathrm{l})$ and $14.7 \mu \mathrm{l}$ of sterile $\mathrm{ddH} 2 \mathrm{O}$. The reaction mixtures were overlaid with a drop of light mineral oil per sample. Amplification was carried out in Techni TC-512 PCR System. The reaction was subjected to one cycle at $95{ }^{\circ} \mathrm{C}$ for 5 minutes, followed by 35 cycles at $96{ }^{\circ} \mathrm{C}$ for 30 seconds, $37^{\circ} \mathrm{C}$ for 30 seconds, and $72{ }^{\circ} \mathrm{C}$ for 30 seconds, then a final cycle of $72^{\circ} \mathrm{C}$ for 5 minutes. PCR products were run at $100 \mathrm{~V}$ for one hour on $1.5 \%$ agarose gels to detect polymorphism between the olive varieties under study. Only four primers succeeded to generate reproducible polymorphic DNA products. The PCR products were separated on a $1.5 \%$ agarose gels and fragments sizes were estimated with the 100bp ladder marker.

Table 1. List of the primer names and their nucleotide sequences used in the study for RAPD procedure.

\begin{tabular}{|ccc|}
\hline No & RAPD Primer code & Sequence \\
\hline 1 & OP-A01 & $5^{\prime}$ CAGGCCCTTC3' \\
2 & OP-A09 & $5^{\prime}$ GGGTAACGCC 3' \\
3 & OP-B02 & $5^{\prime}$ TGATCCCTGG3 $^{\prime}$ \\
4 & OP-C12 & $5^{\prime}$ TGTCATCCCC 3 $^{\prime}$ \\
\hline
\end{tabular}

\section{B- ISSR-PCR Analysis}

ISSR-PCR reactions were conducted using six primers Table (2). Amplification was conducted in $25 \mu \mathrm{l}$ reaction volume containing the following reagents: $2.5 \mu$ of dNTPs $(2.5 \mathrm{mM}), 2.5 \mu \mathrm{MgCl} 2(2.5 \mathrm{mM})$, and $2.5 \mu \mathrm{l}$ of $10 \mathrm{x}$ buffer, $3.0 \mu \mathrm{l}$ of Primer $(10 \mathrm{pmol}), 3.0 \mu \mathrm{l}$ of template DNA $(25 \mathrm{ng} / \mu \mathrm{l}), 1 \mu \mathrm{l}$ of Taq polymerase $(1 \mathrm{U} / \mu \mathrm{l})$ and $12.5 \mu \mathrm{l}$ of sterile $\mathrm{dd} \mathrm{H} 2 \mathrm{O}$. the PCRs were programmed for one cycle at $94^{\circ} \mathrm{C}$ for $4 \mathrm{~min}$. followed by 45 cycles of $1 \mathrm{~min}$. at $94^{\circ} \mathrm{C}, 1 \mathrm{~min}$. at $57^{\circ} \mathrm{C}$, and $2 \mathrm{~min}$ at $72{ }^{\circ} \mathrm{C}$ the reaction was finally stored at $72{ }^{\circ} \mathrm{C}$ for $10 \mathrm{~min}$. the PCR products were separated on a $1.5 \%$ agarose gels and fragments sizes were estimated with the 100bp ladder marker. 
Table 2. List of the primer names and their nucleotide sequences used in the study for ISSR procedure.

\begin{tabular}{|ccc|}
\hline No & ISSR Primer code & Sequence \\
\hline 1 & $44 B$ & $5^{\prime}$ CTC TCT CTC TCT CTC TGC 3' \\
2 & HB-08 & $5^{\prime}$ GAG AGA GAG AGA GG 3' \\
3 & HB-09 & $5^{\prime}$ GTG TGT GTG TGT GC 3 \\
4 & HB-12 & $5^{\prime}$ CAC CAC CAC GC 3 \\
5 & HB-13 & $5^{\prime}$ GAG GAG GAG GC 3 \\
6 & HB-15 & $5^{`}$ GTG GTG GTG GC 3 \\
\hline
\end{tabular}

\section{Statistical analysis:}

The DNA bands generated by each primer were counted and their molecular sizes were compared with those of the DNA markers. The bands scored from DNA profiles generated by each primer were pooled together. Then the presence or absence of each DNA band was treated as a binary character in a data matrix (coded 1 and 0 , respectively) to calculate genetic similarity and to construct dendrogram tree among the studied olive strains. Calculation was achieved using Dice similarity coefficients (Dice, 1945) as implemented in the computer program SPSS-10 (Rohlf, 2000).

\section{RESULTS AND DISCUSSION}

\section{1- Oil content in leaves ( $\mathrm{gm} / \mathbf{1 0 0 g m})$ :}

Data pesented in Table (3) indicated that, The maximum oil percentage of dry leaves was observed in Mraki cultivars $(7.650 \mathrm{ml} /$ plant), while the minimum was observed in Toffahi (4.754 ml/plant).

Table 3. Oil content in leaves of three Egyptian olive cultivars.

\begin{tabular}{|cc|}
\hline Cultivars & Oil content $(\mathrm{gm} / 100 \mathrm{gm})$ \\
\hline Maraki & 7.650 \\
Aggezi Shami & 6.046 \\
Toffahi & 4.754 \\
\hline
\end{tabular}

\section{2- Fatty Acids composition:}

Fatty acids in leaves oils of the cultivars under investigation was presented in table (4). The main fatty acids were Linolenic acid, Oleic acid, and Palmitic acid.

Linolenic acid, represented (39.3, 38.61 and 37.11) in Maraki, Aggezi Shami and Toffahi, respectively. Oleic acid, represented (20.96, 19.81 and 20.81) in Maraki, 
Aggezi Shami and Toffahi, respectively. Palmitic acid, represented (24.71, 23.61 and 23.81) in Maraki, Aggezi Shami and Toffahi, respectively.

Oleic acid was the monounsaturated fatty acid found in all cultivars under study. It was at the highest level in Maraki then Toffahi, and Aggezi Shami. On the other side, Linoleic acid was at highest levels in Toffahi, but the lowest level was detected in Aggezi Shami.

These results are in agreement with the finding of Cavalheiro et al. (2015) on different olive cultivars, who mentioned that oleic acid was the most abundant monounsaturated fatty acid. On the other hand Linolenic acid was the most abundant fatty acids in all cultivars.

Table 4. Fatty Acids composition (\%) of three Egyptian Olive Leaves cultivars.

\begin{tabular}{|cccccc|}
\hline $\begin{array}{c}\text { Peak } \\
\text { No. }\end{array}$ & Fatty acids & $\begin{array}{c}\text { Retention } \\
\text { Time } \\
(\mathrm{min})\end{array}$ & Maraki & $\begin{array}{c}\text { (FA \%) } \\
\text { Aggezi } \\
\text { Shami }\end{array}$ & Toffahi \\
\hline 1 & 9.40 & 1.12 & 1.51 & 1.31 \\
2 & $\begin{array}{c}\text { Myristic acid } \\
\text { C14:0 } \\
\text { Palmitic acid } \\
\text { C16:0 }\end{array}$ & 11.56 & 24.71 & 23.61 & 23.81 \\
3 & $\begin{array}{c}\text { Stearic acid } \\
\text { C18:0 } \\
\text { Oleic acid } \\
\text { C18:1 }\end{array}$ & 14.17 & 4.31 & 4.21 & 4.31 \\
5 & $\begin{array}{c}\text { Linoleic acid } \\
\text { C18:2 } \\
5\end{array}$ & 14.56 & 20.96 & 19.81 & 20.81 \\
6 & $\begin{array}{c}\text { Linolenic acid } \\
\text { C18:3n3 }\end{array}$ & 15.34 & 7.21 & 7.13 & 7.81 \\
7 & Arachidic acid \\
C20:0 & 16.47 & 39.30 & 38.61 & 37.11 \\
\hline
\end{tabular}

\section{2- Molecular Studies}

\section{A- Randomly amplified polymorphic DNA (RAPD) markers}

The four 10-mer arbitrary primers succeeded in amplifying DNA fragments for the three olive cultivars as illustrated in Table (5) and Fig (1). Polymorphism percentage differed from one primer to another. OP-A09 primer exhibited the lowest polymorphism (00.0\%). On the other hand OP-C12 (66.67\%) and OP-B02 (76.92\%) primers exhibited moderate levels of polymorphism. However OP-A01 (95.83\%) primer exhibited high levels of polymorphism. The number of total amplified fragments (TAF), polymorphic fragments (PF), monomorphic fragments (MF) and unique fragment (UF) for each sample using the five primers are shown in Table (5). OP-A02 primer produced twenty four fragments with molecular size ranging from 108 to 629 bp (Fig.1). 
Table 5. Species-specific RAPD and ISSR markers for three Egyptian olive cultivars.

\begin{tabular}{|c|c|c|c|c|c|c|}
\hline Primers code & $\begin{array}{l}\text { Range } \\
\text { of M.W. }\end{array}$ & TAF & MF & PF & UF & $\begin{array}{l}\text { Polymorphi } \\
\text { sm } \\
(\%)\end{array}$ \\
\hline \multicolumn{7}{|l|}{ RAPD primers } \\
\hline OP-A01 & $\begin{array}{l}271- \\
1172\end{array}$ & 16 & 3 & 13 & $\begin{array}{l}\text { 12(271,321,479,567,734,98 } \\
0,1172)-(501,1025)- \\
(443,490,561) \mathrm{bp}\end{array}$ & 81.25 \\
\hline OP-A09 & $\begin{array}{l}294- \\
1785\end{array}$ & 10 & 10 & 0 & 0 & 00.0 \\
\hline OP-B02 & $223-739$ & 13 & 3 & 10 & $\begin{array}{l}9(318,398,435,567)- \\
(305,380,444)-(406,739) b p\end{array}$ & 76.92 \\
\hline $\mathrm{OP}-\mathrm{C} 12$ & $283-645$ & 12 & 4 & 8 & $\begin{array}{l}7(459)-(481,508)- \\
(256,332,503,645) \text { bp }\end{array}$ & 66.67 \\
\hline $\begin{array}{l}\text { Total } \\
\text { ISSR primers }\end{array}$ & & 51 & 20 & 31 & 28 & \\
\hline $44 B$ & $263-864$ & 15 & 4 & 11 & $\begin{array}{l}7(841)-(772,864)- \\
(263,380,477,690) \mathrm{bp}\end{array}$ & 73.33 \\
\hline HB-08 & $199-846$ & 15 & 5 & 10 & $4(448,846)-(278)-(605) b p$ & 66.67 \\
\hline HB-09 & $\begin{array}{l}231- \\
1071\end{array}$ & 19 & 7 & 12 & $\begin{array}{l}9(442,688,789,903)- \\
(247,449,523,560,1071) \mathrm{bp}\end{array}$ & 63.16 \\
\hline HB-12 & $\begin{array}{l}367- \\
1522\end{array}$ & 12 & 6 & 6 & $\begin{array}{l}4(0)- \\
(1522,1369,1208,1086)-(0) \\
\text { bp }\end{array}$ & 50.00 \\
\hline HB-13 & $\begin{array}{l}268- \\
1445\end{array}$ & 15 & 9 & 5 & $4(932,1319,1445)-(464) b p$ & 40.00 \\
\hline HB-15 & $\begin{array}{l}296- \\
1037\end{array}$ & 8 & 6 & 2 & 1(758)bp & 25 \\
\hline Total & & 84 & 37 & 46 & 29 & \\
\hline Total & & 135 & 57 & 77 & 57 & \\
\hline
\end{tabular}

TAF $=$ Total Amplified Fragments, $\quad \mathrm{MF}=$ Monomporphic Fragments, $\mathrm{PF}=$ Polymorphic Fragments, $\mathrm{UF}=$ Unique Fragments.

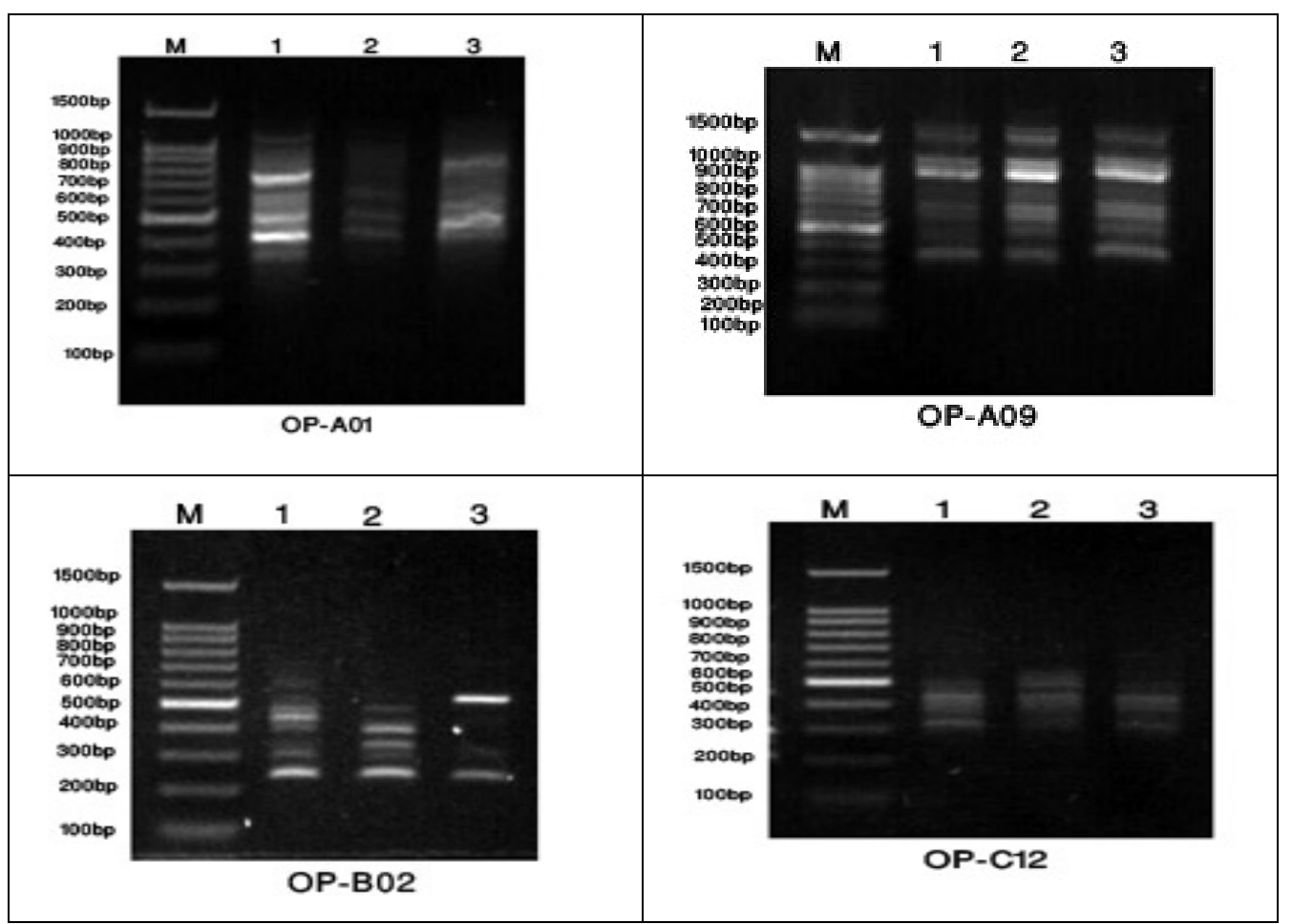

Fig. 1. RAPD-PCR analysis of three Egyptian olive cultivars.
1- Maraki
2- Aggezi Shami
3- Toffahi 
Thirteen fragments were polymorphic (81.25\%) and twelve of them were unique fragments at $(271,321,479,567,734,980,1172)$ bp for Maraki cultivar, (501, 1025) bp for Aggezi Shami cultivar and $(443,490,561)$ bp for Toffahi, while only three fragment was present in all cultivars which is considered as common fragment.

For OP-A09 primer resulted in ten DNA fragments with molecular size ranging from 294 to $1785 \mathrm{bp}$, zero fragments were polymorphic (00.0\%). OP-B02 primer resulted in thirteen DNA fragments with molecular size ranging from 223 to $739 \mathrm{bp}$, ten fragments were polymorphic $(76.92 \%)$, in wich nine of them were unique fragments at $(318,393,435,567)$ bp for Maraki cultivar, $(305,380,444)$ bp for Aggezi Shami cultivar and $(406,738)$ bp for Toffahi cultivar, while the other three fragments were presented in all cultivars which are considered as common fragments. OP-C12 primer resulted in twelve DNA fragments with molecular size ranging from 283 to $645 \mathrm{bp}$, in which eight fragments were polymorphic $(66.67 \%)$ and seven of them were unique fragments at (459) bp for Maraki cultivar, $(481,508)$ bpfor Aggezi Shami cultivar and $(256,332,503$, $645)$ bp for Toffahi and the other four fragments were present in all cultivars which are considered as common fragments.

\section{B- Inter Simple Sequence Repeats (ISSRs) markers:}

The six ISSR primers succeeded in amplifying DNA fragments for the three cultivars (Fig.2). Polymorphism percentage differed from one primer to another, i.e. HB-09, HB-08 and 44B primers exhibited high polymorphism $(63.16 \%, 66.67 \%$ and $73.33 \%)$ respectively, while, (HB-13 and HB-12) primers exhibited moderate polymorphism (40.00\% and $55.00 \%$ ), respectively. HB-15 primer exhibited the lowest polymorphism (25.00 \%) as exhibited in Table (5). 44B Primer showed fifteen DNA fragments with fragments length ranging from 263 to 864 bp (Fig.3 and Table $5)$, elevn fragments were polymorphic $(73.33 \%)$, and seven of them were unique fragments at $(841)$ bp for Maraki cultivar, $(772,864)$ bp for Aggezi Shami cultivar and (263, 380, 477, 690) bp for Toffahi cultivar. HB-08 primer showed fifteen DNA fragments with molecular sizes ranging from 199 to $846 \mathrm{bp}$, ten fragments were polymorphic $(66.67 \%)$, and four of them were unique fragments at $(448,846)$ bp for Maraki cultivar, (278) bp for Aggezi Shami cultivar and (605) bp for Toffahi cultivar. HB-09 primer showed ninteen DNA fragments with fragments length ranging from 231 to $1071 \mathrm{bp}$, twelve fragments were polymorphic (63.16\%), and nine of them were unique fragments at $(442,688,789,903)$ bp for Maraki cultivar and $(247,449,523$, $560,1071)$ bp for Aggezi Shami cultivar. HB-12 primer showed twelve DNA fragments with fragments length ranging from 367 to $1522 \mathrm{bp}$, six fragments of them were polymorphic $(50.00 \%)$, and three of them were unique fragments at $(1522,1369$, 1208, 1086) bp for Aggezi Shami cultivar. HB-13 primer showed fifteen DNA fragments with fragments length ranging from 268 to $1445 \mathrm{bp}$, five fragments were polymorphic $(40.00 \%)$ and four of them were unique fragments at $(932,1319,1445)$ 
bp for Maraki cultivar and (464) bp for Aggezi Shami cultivar. HB-15 primer showed eight DNA fragments with fragments length ranging from 296 to $1037 \mathrm{bp}$, tow fragments of them were polymorphic $(25.00 \%)$ and one of them was unique fragments at (758) bp for Maraki cultivar. and the other six fragment were present in all genotypes which are considered as common fragments.

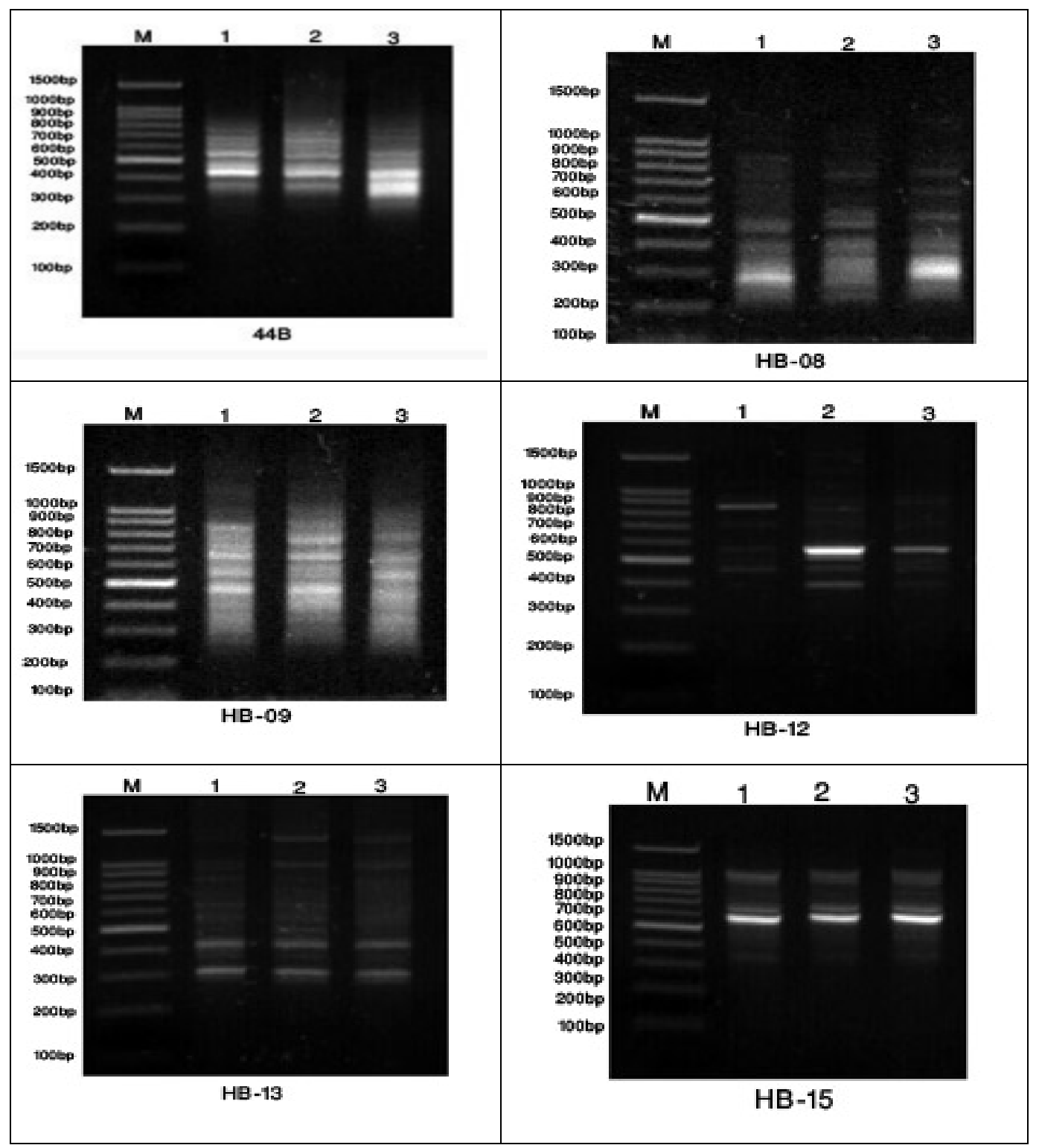

Fig. 2. ISSR-PCR analysis of three egyptian olive cultivars.
1- Maraki
2- Aggezi Shami
3- Toffahi

\section{C- Genetic similarity and cluster analysis based on RAPD markers}

The RAPD data were used to estimate the genetic similarity values among the three olive cultivars by using UPGMA computer analysis (Table 6 and Fig. 1). The highest similarity value (1.0) was recorded between Maraki and Toffahi cultivars, while 
the lowest similarity value (0.167) was detected between Maraki and Aggezi Shami cultivars. On the other hand there was no similarity between Aggezi Shami and Toffahi cultivars.

Table 6. Similarity value (Pairwise comparison) of three Egyptian olive cultivars based on RAPD data

\begin{tabular}{|c|c|c|}
\hline & Maraki & Aggezi Shami \\
\hline Maraki & & \\
\hline Aggezi Shami & 0.167 & \\
\hline Toffahi & 1.000 & 0.000 \\
\hline
\end{tabular}

A dendrogram for the genetic relationship among the three cultivars of olive is exhibited in Fig. (3), which separated them into two groups. The first group included Maraki cultivar, while the second group included Aggezi Shami and Toffahi cultivars.

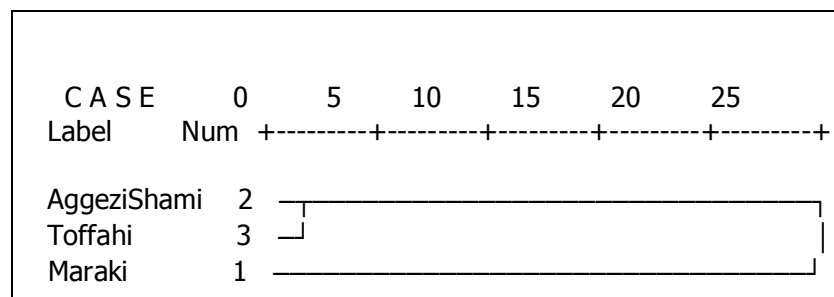

Fig. 3. A dendrogram illustrates the genetic distance for three Egyptian olive cultivars based on RAPD data.

\section{D- Genetic similarity and cluster analysis based on ISSR markers:}

The ISSR data were used to estimate the genetic similarity values among the eight genotypes of Eucalyptus species by using UPGMA computer analysis (Table 7 and Fig.2). The highest similarity values were recorded (1.0) between Maraki and Aggezi Shami cultivars, while the least similarity value $(0.0529)$ was recorded between Maraki and Toffahi cultivars and there was no similarity between Aggezi Shami and Toffahi cultivars. 
Table 7. Similarity value (Pairwise comparison) of three Egyptian olive cultivars based on ISSR data

\begin{tabular}{|c|c|c|}
\hline & Maraki & Aggezi Shami \\
\hline Maraki & & \\
\hline Aggezi Shami & 1.000 & 0.000 \\
\hline Toffahi & 0.529 & \\
\hline
\end{tabular}

A dendrogram for the genetic relationship among the three olive is illustrated in Fig. (4). As they were separated into two groups. The first group included only Maraki cultivar, while the second group included Aggezi Shami and Toffahi Cultivars.

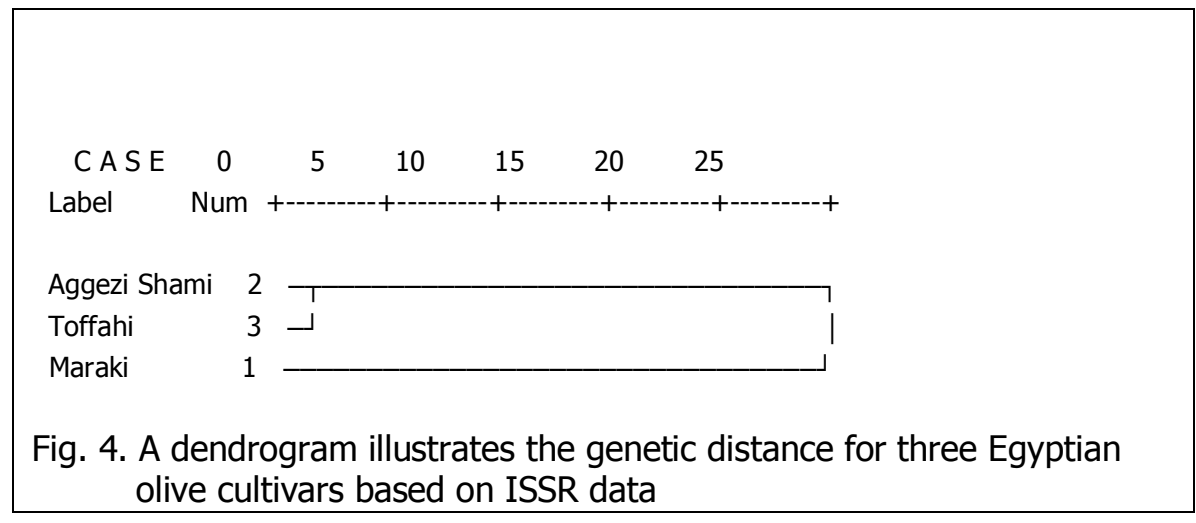

\section{E- Combined identification based on RAPD and ISSR analyses:}

The highest similarity values were recorded (1.0) between Maraki and Toffahi cultivars, while the least similarity value (0.881) was recorded between Maraki and Aggezi Shami cultivars and there was no similarity between Aggezi Shami and Toffahi cultivars (Table 8).

Table 8. Similarity value (Pairwise comparison) of three Egyptian olive cultivars based on over-combination of RAPD and ISSR analysis.

\begin{tabular}{|c|c|c|}
\hline & Maraki & Aggezi Shami \\
\hline Maraki & & \\
\hline Aggezi Shami & 0.881 & \\
\hline Toffahi & 1.000 & 0.000 \\
\hline
\end{tabular}

The dendrogram based on RAPD and ISSR-PCR markers (Fig. 5) separated Maraki cultivar from the other two olive cultivars.

The high polymorphism percentage observed in this study was between the two Egyptian genotypes Aggezi Shami and Toffahi indicated that they are highly polymorphic cultivars (Saeed et al., 2004; Fayek et al., 2014).

In conclusion, ISSR markers are more powerful of these two techniques for fingerprinting closely related cultivars such as those of Olea europea L. cultivars. Although most ISSR alleles are dominant, rather that co-dominant, ISSR amplification of Olea europea L. ISSR markers offers several advantages over RAPDs, the major 
one being rapid production of a large number of markers in a cost-effective manner. ISSR amplification has great potential in plant breading and germoplasm evaluation, especially for fingerprinting narrow-based germoplasm like those present in Olea europea L.

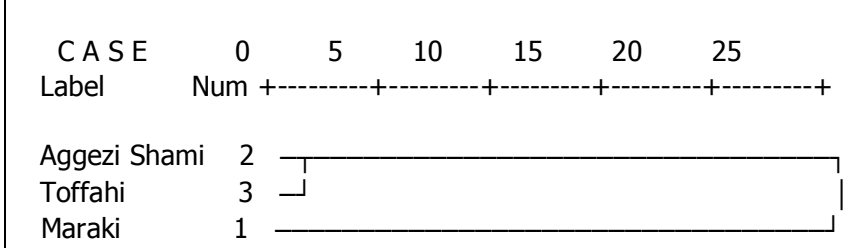

Fig. 5. A dendrogram illustrates the genetic distance for three Egyptian Olive cultivars based on over-combination of RAPD and ISSR analysis.

\section{CONCLUSION}

- Leaves oil and chemical composition has been demonstrated due to the kind of oils extracted from olive cultivars. The oil and its fatty acids compositions have been described above. Such wide differences and the profiles provide a stimulus the effort for further researches and liable to find more new compounds in olive leaves.

-The total unsaturated fatty acids were the highest in Maraki, Aggezi Shami and Toffahi.

- According to the obtained dendrogram of the combination between RAPD and ISSR results, Maraki existed alone in a group because is an olive oil cultivar.

- This study provides evidence that RAPD and ISSR polymorphism could be used as efficient tools for the detection of similarities and phylogenetic relationships of the studied genotypes and this study revealed that the phenotypic was as a result to interaction between the genotypic and ectopic.

\section{ACKNOWLEDGMENTS}

We are thankful to Dr. Mounir Eid, Dr. Sayed Yussif and Dr. Omneya Farouk for their support in any respect during completion of the research.

\section{REFERENCES}

1. A.O.A.C. 2000. Official methods of analysis. Association of Official Analytical Chemists, Fifteenth ed., Arlington, Virginia, USA.

2. Cavalheiro, C. V., Picoloto, R. S., Cichoski, A. J., Wangner, R., De Menezes, C. R., Zepka, L. Q., Da Croce, D. M. and Barin, J. A. 2015. Olive leaves offer more than phenolic compounds - Fatty acids andmineral composition of varieties from Southern BrazilCaroline. Industrial crops and Products, 71:122-127. 
3. Cossignani, L, Simonetti, MS and Damiani, P. 2005. Biocatalyzed acidolysis of olive triacylglycerols with $9 \mathrm{c}, 11 \mathrm{t}$ and $10 \mathrm{t}, 12 \mathrm{c}$ isomers of conjugated linoleic acid. Eur Food Res. Technol. 220, 267-271.

4. Dice, L. R. 1945. Measures of the amount of ecologic association between species. Ecology, 26: 297-302.

5. Essadki, M.; Ouazzani, N.; Lumaret, R. and Moumni, M. 2006. ISSR variation in olive-tree cultivars from Morocco and other western countries of the Mediterranean Basin. Genet. Resour. Crop. Ev., 53(3): 475-482.

6. Fayek, M, A., Abdel-Mohsen, M. A., Laz, S. I. and El-Sayed, S. M. 2014. Morphological, agronomical and genetic characterization of Egyptian olive clones compared with the international cultivars Egypt. J. Hort., 41(1), 1-25.

7. Laz Sanaa, I. and Abd El-Razik, A.B. 2005. DNA fingerprinting and genetic relatedness among some cultivars of oleaeuropaea in Egypt using RAPD and AFLP analysis. Egypt j. Genet, Cyto., 34:331-344.

8. Reddy, M.P.; Sarla, N. and Siddiq, E.A. 2002. Inter simple sequence repeat (ISSR) polymorphism and its application in plant breeding. Euphytica., 128(1), 917.

9. Rohlf, F. J. 2004. On the use of shape to compare morphometric method. Hystrix, Italian, J. Mamm. 11(1): 8-24.

10. Saeed, W. T., Hassan, H. Z., Gazy, S. M. M., and Shaban, E. M. S. 2004. A Molecular fingerprints of some olive (Olea Europaea L.) cultivars in Egypt. Bull. Fac. Agric., Cairo Univ., 56: 341-360.

11. Sanz-Cortés, F.; Badenes, M. L.; Paz, S.; Iniguez, A., AND Llacer, G. 2001. Molecular characterization of olive cultivars using RAPD markers. J Amer Soc Hort Sci., 126(1): 7-12.

12. Therios, I. 2009. Olives (Crop Production Science In Horticulture). CABI Head Office, Nosworty Way, Wallingford, Oxfordshire OX10 8DE. UK, 245-254.

13. Tomić, L.; Štajner, N. and Javornik, B. 2013. Characterization of Grapevines by the Use of Genetic Markers, pp 7. In: Poljuha, D and Sladonja, B (eds) The Mediterranean Genetic Code-Grapevine And Olive. Published by InTech. Janeza Trdine 9, 51000 Rijeka, Croatia.

14. Wiesman, Z. 2009. Desert Olive Oil Cultivation: Advanced Bio Technologies. ${ }^{1 \text { st }}$. Edition. 415p. Israel. Academic Press is an imprint of Elsevier.

15. Williams, J.K.; A.R. Kubelisk, K.J. Livak, J.A. Rafalski. and S.V. Tingey. 1990. DNA polymorphisms amplified by arbitrary primers are useful as genetic markers. Nucleic Acids Research., 18: 6531 - 6535.

16. Zamora, R.; Alaiz, M. and Hidalgo, F.J. 2001. Influence of cultivar and fruit ripening on olive (Olea europaea) fruit protein content, composition, and antioxidant activity. J. Agric. Food Chem., 49(9):4267-4270. 


\section{التعريف الوراثي الجزيئي و التركيب الكيميائي \\ لزيت أوراق بعض أصناف الزيتون المصرية}

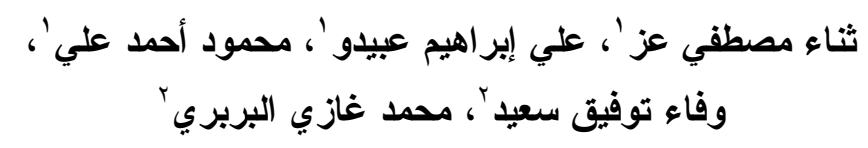

ا ـ . قسم الإنتاج النباتي، كلية الزراعة (سابا باشا)، جامعة الأسكندرية.

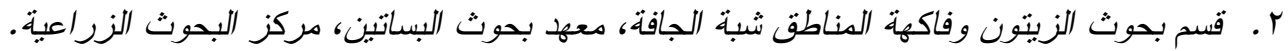

أجرى هذا البحث بهدف دراسة الإختلافات في محتوي أوراق الزيتون من الزيت وكذلك التركيب الكيميائي وذلك لثلاثة من أصناف الزيتون المصرية، كما تم عمل توصيف وراثي جزيئي لها. و الأصناف هي المر اقي والعجيزي الثامي والتفاحي و الموجودة في المزرعة البحثية بمعهد بحوث البساتين، قسم بحوث الزينون وفاكهة المناطق شبة الجافة. وقد وجد أن نسبة محتوي الأور اق وات

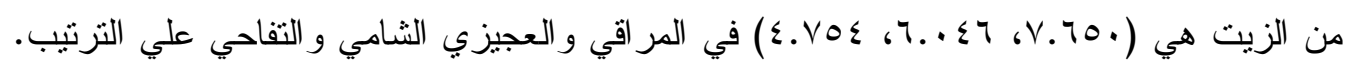
وقد وجد أن أهم الأحماض الدهنية في زيت الأوراق هي حمض اللينولينيك ثم حمض الأوليك ثم حمض البالمنيك.

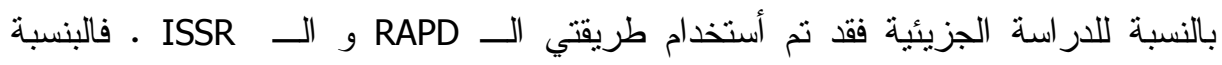
لطريقة الــ RAPD وهى طريقة فعالة فى الكثف عن التتوع أو الأختلافات الور اثثية داخل وبين

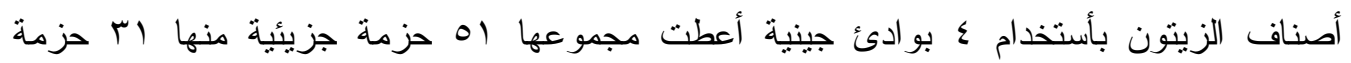

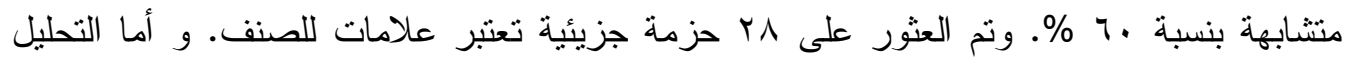

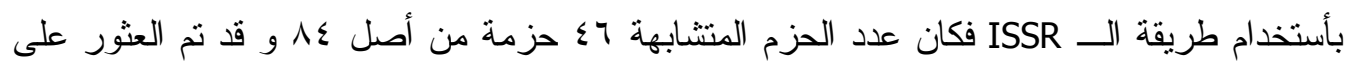

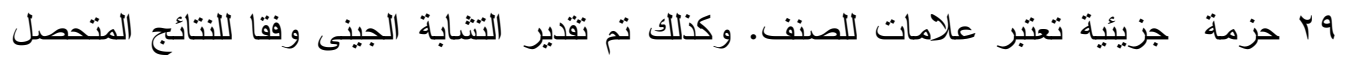

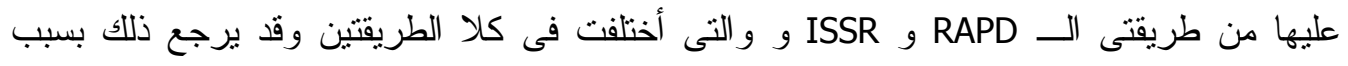
أختلاف كل طريقة فى درجة تضخمها للجينوم. لذا كان من الأفضل أستخدام مزيج من الطريقتين فى شجرة التو افق. تحديد التباين الوراثى للطرز الوراثية كان كافيا بإستخدام الكواثف الجزيئية

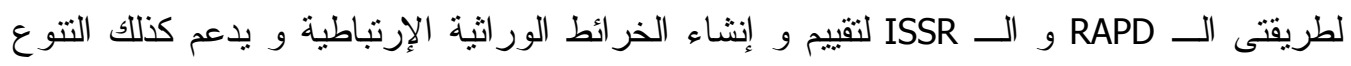
الور اثى لتلك الأصناف و الذي قد يساعد فى بر امج الثربية في المستقبل. 